\title{
Романите на Толстой и киното Руски и неруски рефлексии
}

Константина Пунева / Konstantina Puneva

Софийски университет „Св. Климент Охриски“

Sofia University "St. Kliment Ohridski"

kpuneva@gmail.com

Основен интерес на доклада е съпоставката на руските и неруските екранизации по романите на Толстой („Война и мир“, „Ана Каренина“ и „Възкресение“). Рефератът се фокусира върху универсалните мотиви в екранизациите и приемствеността им през годините. Проблематизирана е и тема за възприемането на руската култура извън пределите на Русия.

Ключови думи: Толстой, романи, „Война и мир“, „Ана Каренина“, „Възкресение“, екранизации, универсални мотиви, рефлексии, обществени нагласи, текст, филм

Tolstoy's Novels and the Cinema. Russian and Non-Russian Reflections

The main intention of the paper is a comparison between the Russian and non-Russian screen adaptations of the novels of Tolstoy (War and Peace, Anna Karenina and Resurrection). The author focuses on the universal motives in adaptation and their continuity over the years. Other key issues include the perception of Russian culture beyond the boundaries of Russia.

Key words: Tolstoy, novels, "War and Peace", "Anna Karenina", "Resurrection", adaptations, universal motifs, reflections, public attitudes, text, film 
Присъствието на Толстой в киното все повече изкушава изследователите и насочва интереса им към екранизациите по великите му романи. Граничната линия между текст и филм, застинало и движещо се изображение, оригинал и екранно копие има особено метафизично проявление, що се отнася до Толстоевите романи. Те предизвикват силен отзвук из целия свят, а първите адаптации се появяват още приживе на автора. При внимателното навлизане в темата няма как да се подмине разграничението руски и неруски рефлексии. Как киноезикът тълкува текста-Толстой в Русия и извън нея? Кои са универсалните мотиви, върху които наблягат режисьорите? Надграждат ли се образите и има ли приемственост между литературния и филмовия им вариант? Достига ли се до същността на концепта, формулиран от Бердяев като „руска душа“? Все въпроси, фундаментални при работата с екранизациите по „Война и мир“, „Ана Каренина“ и „Възкресение“. Бързам още тук да направя уговорката, че в изложението ще се спра само на представителна част от екранизациите. Мащабността на темата не ми позволява да разгърна цялостно проблематиката, затова ще резюмирам фрагментарно основната концепция.

В Русия литературата е органична част от всекидневието, а руският човек респективно е център в творчеството на класиците. В произведенията си те се занимават със събитията и проблемите, вълнуващи съзнанието на обществото, предимно през призмата на руското. В романите на Толстой именно човекът и неговите екзистенциални търсения са основният модус, около който се изгражда сюжетът. На Запад руската културна традиция провокира голям интерес. Но в неруските екранизации често се забелязва невъзможност инстинктивно да се проникне в нея, да се улови атмосферата и да се разрови под повърхността на литературното изображение. В същото време руският човек естествено се потопява и пресъздава усещанията, заложени в романите на Лев Николаевич, защото е носител на същата менталност, върху която се основава собствената му култура.

При адаптирането на романовия материал в сценарий се разминават идеите, заложени в текста, тъй като кинематографистите се стремят да се докоснат до колективното несъзнавано и да накарат зрителя да се самоиндетифицира с главните герои. Тези цели задължават режисьорите да подходят към текста, съобразявайки се с обществените нагласи. От друга страна, многопластовият свят на пи- 
сателя трудно може да бъде цялостно пренесен на филмова лента. Не трябва да забравяме, че „Толстой създава нова естетическа (тоест философско мотивирана) концепция за разбирането и тълкуването на човека“, по думите на руския автор Евгений Костин (Костин 2015: 306). Именно стремежът на автора към описание на живота такъв, какъвто е, човешката същност и обществените отношения, представени възможно най-реалистично и през различни художествени призми, са сред особеностите, придаващи на романите му универсалност и цялостност. Качества, привличащи режисьорите, но и най-проблематични за пресъздаване.

Първият екранизиран роман на Толстой, е „Възкресение“; продукцията е датска. Тук веднага възниква питането защо спонтанният избор на режисьорите не е епическата мощ на „Война и мир“ или социалната и лична драма в „Ана Каренина“, а именно историята на съблазнената и изоставена жена. Сред предпоставките за този избор са частната съдба, силните индивидуалности, психологическите обрати и богатата образност. Отделно, през първите години на киноизкуството технически не е било възможно да се изобразят мащабността и многообразието от характери на предходните два романа. Разбира се, не закъсняват опитите и по тях. Първата филмова разработка на „Ана Каренина“ е немска продукция от 1910 г., а по „Война и мир“ - от 1913 г., дело на руския режисьор Пьотр Чардинин. Фактите показват, че кинематографистите от различни страни се обръщат към творчеството на Толстой още с прохождането на киното. Този интерес не стихва нито за миг и до днес. Актуален пример е последната екранизация на БиБиСи по „Война и мир“ от 2016 г.

Произведенията на писателя намират широк отзвук в целия свят. Обичаните от редица поколения сюжети привличат с нетрадиционния поглед към вечно актуални обществени теми, с общочовешката си проблематика и смелите ракурси на нейното интерпретиране. Посягайки към Толстой, задачата на кинематографистите се улеснява, защото устойчивите черти на героите спомагат за лесното им визуално пресъздаване. От друга страна, съвременният зрител често е „двойно“ запознат със сюжетите. Веднъж от текстовете и втори път от филмите. Така в представата на публиката има предпоставени очаквания, които с всяка нова екранна транскрипция трябва да се надградят. Тези особености са присъщи за всяко литературно произведение, пренесено на екрана, но са особено важни при Толстоевите романи, 
реинкарнирани десетки пъти: факт, допълнително затрудняващ кинотворците. Те трябва да решат дали да доизградят образите, познати от екрана, или да се завърнат към текста и да го представят с напълно нова концепция. Затова по-често се съобразяват със съвременното мислене за литература и кино, а появата на нова екранизация почти винаги се е превръщала в събитие. Сред филмите, превърнали се в етапни, се открояват „Война и мир“ на Кинг Видор (1956), на Сергей Бондарчук от (1965), на Робърт Дорнхелм (2007); „Ана Каренина“ на Кларънс Браун (1935), на Жулиен Дювивие (1948), на Александър Зархй (1967), на Бърнард Роуз от 1997 г., на Сергей Соловьов (2009) и адаптацията на Джо Райт (2012), а останали в историята екранизации на „Възкресение“ са само три - от 1909 г. на Дейвид Грифит, от 1960 г. на Михаил Швейцер и от 2001 г. на братя Тавиани. Това изброяване е необходимо, за да се представи нагледно интересът на режисьорите в Русия и извън пределите ѝ . Девет от изброените общо дванайсет филма са неруски - именно онези, които обикновено биват „обвинявани“, че не успяват да разберат и пресъздадат мирогледа на Толстой към света. Далечни на руската култура, те в повечето случаи, не проникват в руския дух, оставайки на повърхността на наратива.

Наблюдават се няколко общи тенденции, които трябва да се откроят в самото начало. В центъра на филмите, независимо за кой от трите романа става въпрос, на преден план стоят личните драми и взаимоотношения. В първите години от филмографията адаптациите се доближават до мелодраматизма, а главните герои са наивистично пресъздадени. С развитието на езика на киното режисьорите все повече наблягат на различни мотивации в действията и решенията на персонажите. Филмите диалогизират помежду си, като особено интересни са руските отговори на западни екранни версии. За пример могат да послужат филмът на Бондарчук, появил се десет години след успешната американска версия на Кинг Видор от 1956 г., както и опитът на Александър Зархй от 1967 г., полумизиращ с предишните английски и американски продукции по „Ана Каренина“.

По повод американската адаптация на „Война и мир“ Видор Шкловски пише, че тя оставя у руснака чувство за вина, защото не е намерила своята съдържателна екранна версия в Русия. И допълва, че „не трябва да се обръщаш към великите класици заради събитийната част от произведенията им, а за да се научиш от тях как да анализираш живота“ (Шкловский 1985: 287). 
Между филма на Кинг Видор от 1956 г. и екранизацията на Бондарчук от 1965 г. се наблюдава пълно разграничаване в изграждането на образите и тяхната мотировка. Бондарчук се придържа плътно към текста, но в същото време успява да го пренапише на езика на киното. В своята монография Лев Анинский посочва много важен факт за подхода на двамата режисьори: Видор се ориентира и изгражда сюжета според събитията в романа, а Бондарчук следва атмосферата на действието и духа на текста. Интересен факт е, че самият Бондарчук се посвещава изяло на филма. Няколко години той „живее“ със сюжета, изучава „вселената“ Толстой и я разглежда като цялостно явление. Към разработката на образите е подходено с умисъл и внимание към всеки детайл. Изготвят се точни копия на костюми от началото на XIX в., табакери, копчета, нашивки, оръжия и т. н. И Видор, и Бондарчук съзнават, че тематиката на романа няма как да привлече със своята актуалност на събитията ${ }^{1}$, затова трябва да се наблегне на пищните и колоритни балове, спецификата на взаимоотношенията в руското общество в началото на XIX в., индивидуалните черти на героите. В това отношение и двамата успяват да създадат забележителни и завладяващи сцени, които остават в съзнанието на зрителя.

Вглеждайки се в екранизациите на „Ана Каренина“, отново откриваме подобна ситуация през 6о-те години². Александър Зархй прави своя опит не на последно място и като отговор на популярните филми с Грета Гарбо от 1935 г. (първата звукова лента по романа) и Вивиан Лий от 1948 г. Техни режисьори са съответно Кларънс Браун и Жулиен Дювивие. Тук изпъква амалгамата между роман, мит и филмов език. Двете версии се фокусират върху любовния триъгълник Ана-Каренин-Вронски, а Кити и Левин са напълно омаловажени като персонажи. Набляга се на драматизма във взаимоотношенията на основните герои, а критиката към многоликото руско общество е избегната. Героините на Грета Гарбо и Вивиан Лий успяват да изградят силни образи, но при тях липсва експлицитно изведена идеята за греха и последствията от него. Екранизацията от Кларънс Браун пра-

1 Средпредпоставките Бондарчукдаекранизира „Война имир“енаближаващата тогава 150-годишнина от Бородинската битка. Самият филм започва да се снима през 1960 г. Не трябва да се пропуска и желанието от страна на Съветска Русия да отговори на успешната американска версия на Кинг Видор.

2 Именно около 6о-те години се появяват филми с усложнена образност, цялостно представяне на сюжетните линии. 
ви и най-големите размествания спрямо литературното произведение. Тук Вронски е този, който изоставя Ана, за да отиде на фронта, докато в романа героят предприема съдбовната крачка след самоубийството на героинята.

У Зархй експлицитно се открояват редица промени от предходните филми. Адаптацията на режисьора акцентно засяга темата за еманципацията на жената. Според киноведа Лев Анински не Ана (Татяна Самойлова) е „инициатор и източник на драматизма, водещ до нейната гибел“ (Анинский 1980: 325), а първопричина за трагедията е Вронски. Тяхната любов е представена като изблик на страст, която ги повлича към неизбежния край. Вронски, за разлика от адаптацията на Браун, не е изобразен като съблазнител, а като човек, изпитващ необходимост от духовна близост, но и неможещ да я открие.

Следващата важна адаптация на „Ана Каренина“ е американска продукция от 1997 г., в която чувствеността и еманципацията се издигат на съвсем ново ниво. Бърнард Роуз е почерпил вдъхновение от предишните запомнящи се образи на Ана, за да изгради своята концепция за героинята. За разлика от предходните неруски екранизации, филмът изгражда пълноценно персонажите на Левин и Кити, а историята на Ана е представена като по-малко значима „смес от мита за прелюбодейство, литературния текст и неговите филмовия варианти“ (Makoveeva 2007: 105). Екипът се възползва от възможността да заснеме част от сцените в Русия, която не е била достъпна за предишните неруски версии поради комунистическия режим. Стремежът да се пресъздаде руският човек и дух прозират както в местата, костюмите, така и в музиката, подбрана за екранизацията - фонът често е запълнен с Прокофиев, Чайковски и Рахманинов. Роуз реанимира американските адаптации, но както отбелязва изследователката Ирина Маковеева, той се разграничава от клишетата, свързани с руската култура, и подхожда към сюжета, включвайки елементи от високата култура - балет, музика, архитектура, литература. Въпреки това изпълнението на Софи Марсо не успява да засенчи превъплъщенията на Грета Гарбо и Татяна Самойлова.

Първата руска версия след разпадането на Съветския съюз се появява през 2009 г. Неин режисьор е Сергей Соловьов, а в главната роля виждаме Татяна Дубрич. Решенията на екипа тук на места достигат крайности, а по думите на киноведа Геновева Димитрова: „екранният вариант на Соловьов, въпреки обилния оригинален текст и 
ремарките, е ампутиран и от любов, и от Толстоевия полифонизъм“ (Димитрова 2011: 99). В образа на Ана са инфилтрирани голяма доза експресивност и крайни емоционални състояния. Подходът на режисьора донякъде е обоснован от желанието да се разграничи изцяло от предходните силни образи на Ана и да провокира зрителя със своя концепция и мотировка на персонажите. Последната филмова версия на романа е английската продукция на Джо Райт от 2012 г. Тя е важна със своя творчески подход и балансирането между литература, театър и кино. Силните емоции, ревността, всепоглъщащата страст и тук са поставени в центъра на взаимоотношенията между Ана (Кийра Найтли) и Вронски (Аарон Джонсън). Не е изненадващо, че отново, както в адаптацията на Роуз, е подчертано прибягването към опиума. Сексуалността, опияняващите субстанции, еманципацията на жената са теми, които са особено актуални през последните десетилетия. Чрез сюжета на Толстой режисьорите съумяват да развият значими социални теми.

Това твърдение се отнася цялостно и за адаптациите на „Възкресение“. Романът има над двайсет екранни версии, но повечето от тях не са запазени. Към сюжета се насочват режисьори буквално от цял свят - Русия, САЩ, Дания, Франция, Италия, Германия, Индия, Япония, Мексико и др. Първият съхранен филм е на Дейвид Грифит от 1909 г. Актрисата, която изпълнява Катюша, е Фло Лорънс - една от първите кинозвезди в Америка. Екранизацията впечатлява със зрялата си за младото и все още прохождащо изкуство кинематографична мисъл, целенасочената употреба на монтажа, работата с камерата. Богатото разнообразие от образи в романа на Толстой е напълно пренебрегнато, като във версията на Грифит липсват темите за политическата и църковната системи, лицемерието, несъстоятелността на институциите. Режисьорът залага на любовните взаимоотношения и комичните елементи, привличащи интереса на публиката. Във филма на Михаил Швейцер от 1960 г. социалната картина е многостранно изобразена, поставен е акцент върху контраста между бедни и богати, фалша и чистите човешки отношения. Режисьорът внимателно следва повествованието на първата част на романа, като дори се придържа към непрекъснатите ретроспективни връщания на Нехлюдов към миналото. Швейцер акцентира на епизоди, важни за промяната на мирогледа на Димитрий и Катюша. Толстой застъпва тезата, че пред младите има две възможности - да съхранят и разви- 
ят добрите си качества, или да се поддадат на материалните и егоистични навици, водещи до разруха на моралните устои. За руския режисьор последиците от житейските избори са важни и именно те са изведени в екранизацията. Филмът успява да въздейства със своята мрачна тоналност, дълбоки и същностни душевни противоречия, добра актьорска игра и правилно разчитане на Толстоевата ирония към обществените нагласи в произведението.

Накрая ще спра вниманието си върху адаптацията на братя Тавиани от 2001 г. В нея е отделено специално внимание на моментите, в които персонажите са изправени пред силен душевен потрес. Успешно е уловен духът на романа. Забележителна например е трансформацията на Катюша от невинно момиче в зряла и груба проститутка. Стефания Рока и Тимоти Пийч пресъздават достоверно метаморфозите в характерите на Маслова и Нехлюдов, както и силната им емоционална натовареност. Руската душа, нейните падения и въздигания са интерпретирани завидно убедително за една чужда екранизация.

След направения обзор трябва да се посочи и важна особеност, свързана с главните персонажи в произведенията: тенденцията към деконструкция на романовите образи. Режисьорите все по-рядко се съобразяват с авторовите описания (физически и душевни), които са изключително точни, плътни и ярки. Първо виждаме чернокосата и черноока Наташа със сини очи (Людмила Савелиева), а в последствие русокоса (Клеманс Поези и Лили Джеймс). В първите адаптации режисьорите се стремят да уловят нейната замечтаност, бърза смяна на настроенията, детска невинност и постепенно съзряване. В последната версия на „Война и мир“ на режисьора Том Харпър пред нас е една съвсем различна Наташа, поразяваща със своята зрялост от самото начало на мини сериала. Ана Каренина също претърпява редица трансформации - от пищна жена в романа на Лев Николаевич, каквато е представена единствено в адаптацията на Зархй, през по-често фина героиня, за да се стигне до екстремно слабата фигура на Кийра Найтли.

В екранизациите откриваме забележителна дифузия между литература и кино. Периодичното връщане към сюжетите на големите романи на Толстой показват и необходимостта от неговата мъдрост. Актуални и устойчиви теми се оказват чисто човешките емоции, преплитането на съдбите на героите, отстояването на тяхната индивиду- 
алност и борбата им с живота. Дали на фронтовата линия, в балните зали, или в затвора именно проявлението на живота, такъв какъвто е, е универсалният мотив, върху който залагат всички режисьори. Друг подход към големите романи на Толстой не би бил възможен.

\section{Използвана литература}

Анински 1980: $\Lambda$. Анинский. Аев Толстой и кинематограф. Москва

Аимитрова 2011: Г. Аимитрова. Въртележки на абсурда. Руското играхно кино (г99-2огі). София.

Костин 2015: Е. Костин. Аостоевский против Толстого: русская митература и судьба России. СПб

Николски 2009: С. Никольский. Русское мировоззрение. Том II. <http://iphras.ru/pages0746608.htm>. (01.03.2017)

Моковеева 2007: I. Makoveeva. Visualizing Anna Karenina. University of Pittsburgh.

Шкловски 1985: В. Шкиовский. За 60 мет: Работы о кино. Москва

Чернишева 2016: В. Чернышева. Как снимали фимьм "Война и мир" - $\quad$ <https://rg.ru/2016/03/r6/kak-snimali-film-vojna-i-mir.html>. (01.03.2017) 